Prepared as part of the National Water-Quality Assessment Program, Source Water-Quality Assessment

\title{
Organic Compounds in Elm Fork Trinity River Water Used for Public Supply near Carrollton, Texas, 2002-05
}

\begin{abstract}
Organic compounds studied in this U.S. Geological Survey (USGS) assessment generally are man-made, including pesticides, solvents, gasoline hydrocarbons, personal-care and domestic-use products, refrigerants, and propellants. A total of 103 of 277 compounds were detected at least once among the 30 samples of source water for a community water system on the Elm Fork Trinity River near Carrollton, Texas, collected approximately monthly during 2002-05. The diversity of compounds detected indicates a variety of different sources and uses (including wastewater discharge, industrial, agricultural, domestic, and others) and different pathways (including overland runoff and groundwater discharge) to drinking-water supplies. Nine compounds were detected year-round in sourcewater samples, including chloroform, methyl tert-butyl ether (MTBE), and selected herbicide compounds commonly used in the Trinity River Basin and in other urban areas across the United States. About 90 percent of the 42 compounds detected most frequently in source water (in at least 20 percent of the samples) also were detected most frequently in finished water (after treatment but before distribution). Concentrations for all detected compounds in source and finished water generally were less than 0.1 microgram per liter and always less than human-health benchmarks, which are available for about one-half of the detected compounds.
\end{abstract}

\section{Introduction}

An investigation by the National WaterQuality Assessment (NAWQA) Program of the USGS characterizes the occurrence of 277 organic compounds in source water (stream water collected before treatment) and finished water (treated water before distribution) at a community water system near Carrollton, Texas, that uses the Elm Fork Trinity River, a tributary of the Trinity River, as a source of water supply (fig. 1). Samples were collected approximately monthly from the Elm Fork Trinity River during 2002-05 and comprised 30 source- and 13 finished-water samples. The samples were analyzed for pesticides and selected pesticide degradates (or "breakdown products"), solvents, gasoline hydrocarbons, disinfection by-products, and personal-care and domestic-use products.

Community water systems are required to monitor for compounds regulated under the Safe Drinking Water Act. Most of the compounds included in this study are not regulated under U.S. Environmental Protection Agency (USEPA) Federal drinking-water standards (U.S. Environmental Protection Agency, 2007a). The Elm Fork Trinity River study is part of an ongoing national NAWQA investigation covering nine community water systems across the United States. More detailed information and references on the sampling design, methodology, specific compounds monitored, and the national study are described by Carter and others (2007). Additional USGS information on water quality in the Trinity River Basin is available in a companion NAWQA study (Land and others, 1998).
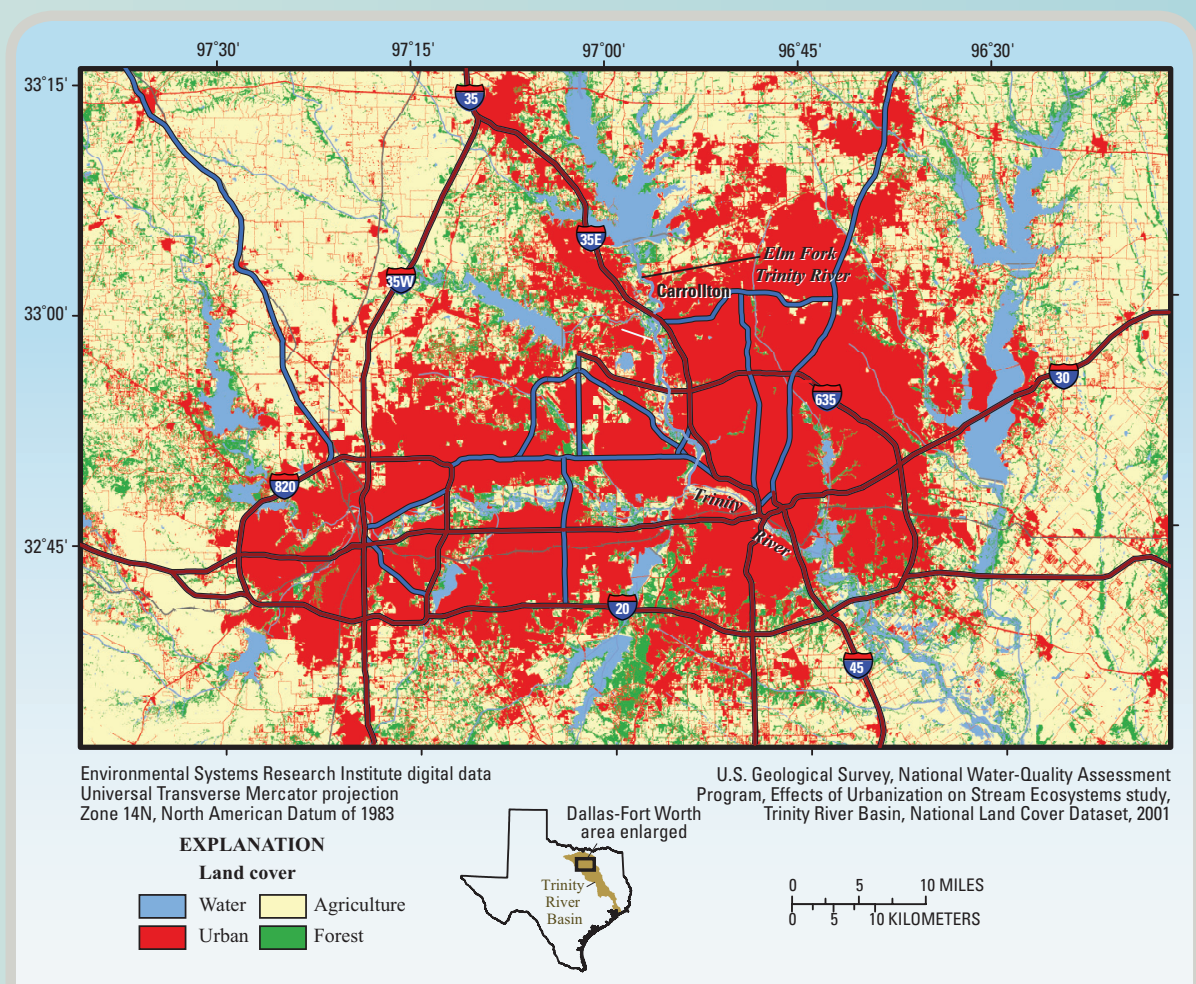

Figure 1. The Trinity River Basin drains 18,000 square miles, all in Texas, and originates above the Dallas-Fort Worth metropolitan area, which has a population of more than 3 million people. There is a large demand for water in this region, and most of the sources of drinking water are from reservoirs and streams in the Trinity River Basin. One source of drinking water is the Elm Fork Trinity River, a tributary of the Trinity River (Land, 1991). 


\section{Occurrence of Organic Compounds in Source Water}

More than one-third of the 277 compounds were detected in at least one source-water sample. These compounds represent many different sources and uses and include pesticides, solvents, gasoline hydrocarbons, and personal-care products. Nine compounds were detected year-round, including selected herbicide compounds commonly used in the Trinity River Basin.

Recent advances in laboratory analytical methods have given scientists the tools to detect a wide variety of contaminants in the environment at low concentrations-often 100 to 1,000 times lower than drinking-water standards (see inset, "What 'Detections' Might Mean to Human Health"). Of the 277 compounds, 103 were detected in at least one source-water sample from the Elm Fork Trinity River; 174 compounds were not detected in any sample.

Forty-two compounds were detected in at least 20 percent of the source-water samples (table 1). Overall, the compounds detected most frequently in water from the Elm Fork Trinity River are among those most frequently detected in ambient stream water in the Trinity River Basin (Land and others, 1998) and across the Nation (Gilliom and others, 2006).

Nine compounds were detected year-round (in more than 95 percent of the source-water samples). The continuous occurrence of these nine compounds might be attributed to upstream groundwater discharge or treated wastewater discharge from municipalities, or both (Kingsbury and others, 2008). Three of

\section{What “Detections" Might Mean to Human Health}

The analytical methods used in this study have low detection levels - often 100 to 1,000 times lower than Federal and State standards and guidelines for protecting water quality. Detections, therefore, do not necessarily indicate a concern to human health but rather help to identify the environmental presence of a wide variety of chemicals not commonly monitored in water resources and help to track changes in their occurrence and concentrations over time. These findings complement ongoing drinking-water monitoring required by Federal, State, and local programs, which focus primarily on post-treatment compliance monitoring of contaminants regulated by USEPA in drinking water. Many of the compounds analyzed by USGS are not included in other source-water and finished-water monitoring programs such as the Unregulated Contaminant Monitoring Program (U.S. Environmental Protection Agency, 2007b, c) and the U.S. Department of Agriculture Pesticide Data Program (U.S. Department of Agriculture, 2008).

the compounds include the herbicides atrazine, metolachlor, and simazine, which commonly are used on row crops and for weed control in urban and residential areas in the Trinity River Basin and across the Nation (Land and Brown, 1996; Land and others, 1998; Gilliom and others, 2006). Herbicide degradates, including deethylatrazine (DEA), deisopropylatrazine (DIA), and 2-hydroxyatrazine, also were present year-round. The three other compounds detected year-round were diuron, another herbicide; MTBE, a gasoline oxygenate; and chloroform, a disinfection by-product.

Table 1. One hundred three of 277 organic compounds were detected frequently (in at least 20 percent of the samples) in source water or finished water, or both. Forty-two compounds were detected in source water, and about 90 percent of these compounds (38) also were detected frequently in finished water. The diversity of compounds indicates a variety of different uses (including industrial, agricultural, and domestic) and different pathways (including treated wastewater outfalls located upstream, overland runoff, and groundwater discharge) of the compounds entering drinking-water supplies.

[Black text, compounds detected in source and finished water; blue text, compounds detected in source water only; green text, compounds detected in finished

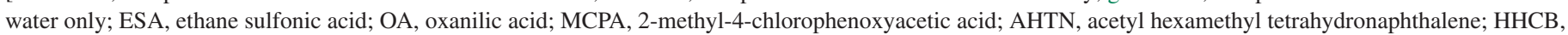
hexadydrohexamethyl cyclopentabenzopyran]

\begin{tabular}{|c|c|c|}
\hline Herbicides and herbicide degradates & Manufacturing additives & Disinfection by-products \\
\hline $2,4-\mathrm{D}$ & Bisphenol A & Bromodichloromethane \\
\hline 2-Hydroxyatrazine & Tri(2-butoxyethyl)phosphate & Bromoform \\
\hline 3,4-Dichloroaniline & Tri(2-chloroethyl)phosphate & Chloroform \\
\hline Alachlor & Tributyl phosphate & Dibromochloromethane \\
\hline Alachlor ESA & Triphenyl phosphate & Solvents \\
\hline Alachlor OA & Tris(dichlorisopropyl)phosphate & Acetone \\
\hline Deethylatrazine (DEA) & AHTN & Methyl ethyl ketone \\
\hline Deisopropylatrazine (DIA) & Caffeine & Methylene chloride \\
\hline Diuron & Camphor & Gasoline hydrocarbons and oxygenates \\
\hline MCPA & HHCB & Benzene \\
\hline Metolachlor & Methyl salicylate & Methyl tert-butyl ether (MTBE) \\
\hline \multirow[t]{3}{*}{ Tebuthiuron } & Desulfinylfipronil & Chloromethane \\
\hline & Diazinon & Fumigant-related compounds \\
\hline & Fipronil & 1,4-Dichlorobenzene \\
\hline
\end{tabular}




\section{Comparisons between Source Water and Finished Water}

About 90 percent of the compounds detected most frequently in source water also were detected most frequently in finished water, and generally at similar concentrations, typically less than 0.1 microgram per liter.

Comparisons between source water and finished water are not intended to characterize treatment efficacy, but to provide a preliminary indication of the potential importance of compounds detected in source water to the quality of finished water before distribution (see inset, "Finished-Water Sampling, Water Treatment, and Significance of Comparisons to Source Water").

Thirty-eight of the 42 most frequently detected organic compounds in source water also were frequently detected in finished water, and often at similar low-level concentrations. Of the 42 most frequently detected organic compounds in source water, the four that were not detected in finished water were methyl salicylate, carbaryl, tert-butyl alcohol, and 1,4-dichlorobenzene. Three other compounds (diazinon, fipronil, and 3,4-dichloroaniline) were detected frequently in source water but only had one or two detections in finished water (fig. 2; table 1). Some of these compounds might be degraded or transformed during the treatment process (Magara and others, 1994; Valder and others, 2008). Atrazine and simazine, commonly used herbicides, were detected in 100 percent of source- and finished-water samples (fig. 2; table 2).

Four organic compounds were detected frequently in finished water but not detected in source water-bromoform, carbon tetrachloride, methyl ethyl ketone, and chloromethane. Four other organic compounds were detected more often in

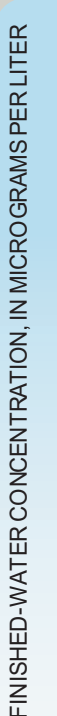

1
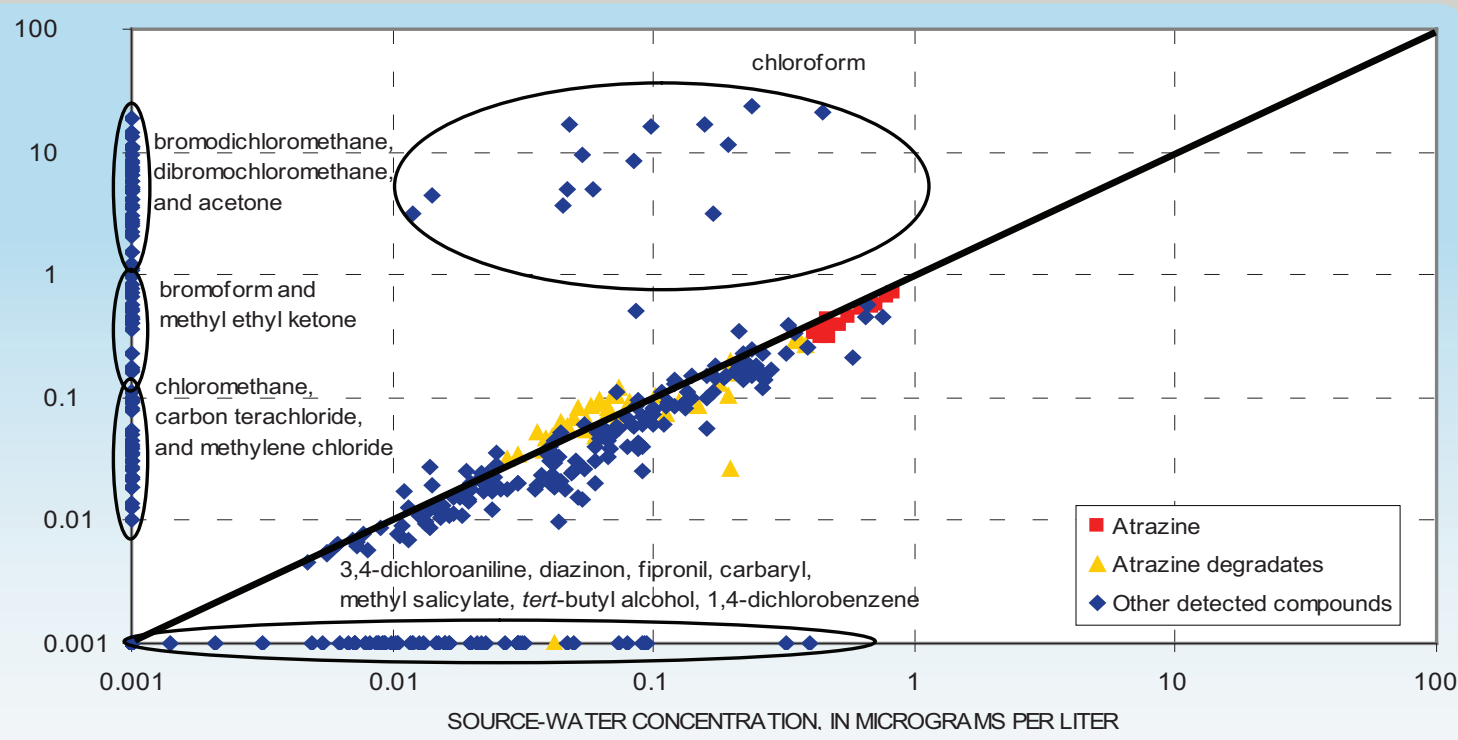

Figure 2. Thirty-eight of the 42 compounds frequently detected in source water also were frequently detected in finished water, often at similar low-level concentrations. Some compounds frequently detected in source water were removed or transformed during treatment and therefore were not detected in finished water. Other compounds were detected only in finished water, which might be residual effects during the water-treatment process.
Finished-Water Sampling, Water Treatment, and Significance of Comparisions to Source Water

The City of Dallas uses conventional water treatment at the site near Carrollton: coagulation/flocculation using ferric sulfate and polymers; sedimentation; filtration through anthracite carbon; disinfection with chloramine; addition of fluorosilicic acid to prevent tooth decay; and addition of lime as a softening agent. Finished-water samples were collected approximately 4 hours after source-water samples to account for treatment plant retention time of the water (Kenneth DelRegno, City of Dallas, oral commun., 2004). Some differences between sourceand finished-water quality might be attributable to changes in source-water quality that are not represented by the finishedwater samples because of sample timing and variations in retention time, and potential analytic variability associated with low concentrations at or near laboratory reporting levels (Kingsbury and others, 2008). It is also possible that some compounds detected in source water were transformed during the treatment process into compounds that were not monitored as part of this study.

The study sampling design and resulting comparisons are not intended to characterize treatment efficacy, but to provide a preliminary indication of the potential importance of compounds detected in source water to the quality of finished water before distribution. In general, conventional treatment is not specifically designed to remove most of the organic compounds monitored in this study.

finished water than in source water-bromodichloromethane, dibromochloromethane, acetone, and methylene chloride. The presence of disinfection by-products, such as bromodichloromethane, bromoform, and dibromochloromethane, in finished water is well documented, understood, and regulated, and is an expected outcome of drinking-water disinfection (Rook,

1974; Krasner and others, 2006). Acetone, methyl ethyl ketone, and methylene chloride are solvents, and their occurrence in finished water is not fully understood. The source of lowlevel concentrations of carbon tetrachloride in finished water samples might be due to its presence as a contaminant in the chlorine used for disinfection (Christman, 1980), or possibly as a disinfection by-product (Krasner and others, 2006). 
Table 2. Fewer than 20 compounds that were detected frequently in source or finished water, or both, had concentrations greater than 0.1 microgram per liter. None of these concentrations exceeded a human-health benchmark; however, benchmarks are only available for 11 of the 19 compounds included in this table.

[ $\mu \mathrm{g} / \mathrm{L}$, micrograms per liter; MCL, maximum contaminant level; HBSL, health-based screening level; THMs, trihalomethanes; ND, not detected; E, estimated; --, no data; OA, oxanilic acid; HHCB, hexadydrohexamethyl cyclopentabenzopyran]

\begin{tabular}{|c|c|c|c|c|c|c|c|c|}
\hline \multirow{2}{*}{ Name of compound } & \multicolumn{2}{|c|}{ Number of samples } & \multicolumn{2}{|c|}{$\begin{array}{l}\text { Percentage } \\
\text { occurrence }^{1}\end{array}$} & \multirow{2}{*}{$\begin{array}{c}\text { Reporting } \\
\text { level }^{2} \\
\text { ( } \mu \mathrm{g} / \mathrm{L} \text { ) }\end{array}$} & \multirow{2}{*}{$\begin{array}{c}\text { MCL or } \\
\text { HBSL }^{3} \\
\text { ( } \mu \mathrm{g} / \mathrm{L})\end{array}$} & \multicolumn{2}{|c|}{$\begin{array}{c}\text { Maximum concentration } \\
(\mu \mathrm{g} / \mathrm{L})\end{array}$} \\
\hline & $\begin{array}{l}\text { Source } \\
\text { water }\end{array}$ & $\begin{array}{l}\text { Finished } \\
\text { water }\end{array}$ & $\begin{array}{l}\text { Source } \\
\text { water }\end{array}$ & $\begin{array}{c}\text { Finished } \\
\text { water }\end{array}$ & & & $\begin{array}{l}\text { Source } \\
\text { water }\end{array}$ & $\begin{array}{c}\text { Finished } \\
\text { water }\end{array}$ \\
\hline \multicolumn{9}{|c|}{ Disinfection by-products } \\
\hline Bromodichloromethane & 30 & 13 & 13 & 100 & 0.04 & \multirow{4}{*}{$\begin{array}{c}80 \text { for } \\
\text { total } \\
\text { THMs }\end{array}$} & 0.28 & 18.85 \\
\hline Bromoform & 30 & 13 & 0 & 100 & .10 & & ND & 1.07 \\
\hline Chloroform & 30 & 13 & 50 & 100 & .02 & & .56 & 23.52 \\
\hline Dibromochloromethane & 30 & 13 & 3 & 100 & .18 & & E.165 & 10.57 \\
\hline \multicolumn{9}{|c|}{ Gasoline hydrocarbons and oxygenates } \\
\hline Methy tert-butyl ether & 30 & 13 & 80 & 77 & .1 & -- & 3.44 & .56 \\
\hline tert-Butyl alcohol & 23 & 6 & 35 & 0 & 1.0 & -- & 1.05 & ND \\
\hline \multicolumn{9}{|c|}{ Herbicides and herbicide degradates } \\
\hline $2,4-\mathrm{D}$ & 30 & 13 & 27 & 15 & .040 & 70 & 4.78 & .459 \\
\hline 2-Hydroxyatrazine & 30 & 13 & 100 & 69 & .080 & 70 & .68 & .301 \\
\hline Alachlor OA & 13 & 13 & 38 & 15 & .020 & -- & .26 & .120 \\
\hline Atrazine & 30 & 13 & 100 & 100 & .007 & 3 & 1.37 & .706 \\
\hline Deethylatrazine (DEA) & 30 & 13 & 27 & 23 & .014 & -- & .136 & .105 \\
\hline Simazine & 30 & 13 & 100 & 100 & .006 & 4 & 1.75 & .454 \\
\hline \multicolumn{9}{|c|}{ Manufacturing additives } \\
\hline Bisphenol A & 29 & 12 & 17 & 25 & 1.0 & 400 & E.32 & E.44 \\
\hline Tri(2-butoxyethyl)phosphate & 30 & 13 & 43 & 23 & .5 & -- & .93 & .56 \\
\hline Tri(2-chloroethyl)phosphate & 30 & 13 & 30 & 15 & .5 & -- & E.16 & E.13 \\
\hline \multicolumn{9}{|c|}{ Personal-care and domestic-use products } \\
\hline Caffeine & 30 & 13 & 17 & 38 & .04 & -- & .58 & .22 \\
\hline НHCB & 30 & 13 & 50 & 0 & .50 & -- & E.26 & E.096 \\
\hline \multicolumn{9}{|c|}{ Solvents } \\
\hline Acetone & 30 & 13 & 7 & 100 & 6 & 6,000 & E1.55 & 11.19 \\
\hline Methyl ethyl ketone & 30 & 13 & 0 & 31 & 2 & 4,000 & ND & E .98 \\
\hline $\begin{array}{l}{ }^{1} \text { Percentage occurrence of samp } \\
{ }^{2} \text { Reporting level shown is highe } \\
{ }^{3} \mathrm{MCL} \text { in bold (U.S. Environme } \\
{ }^{4} \text { Total THMs include bromodic }\end{array}$ & $\begin{array}{l}\text { with conce } \\
\text { alue of eith } \\
1 \text { Protection }\end{array}$ & $\begin{array}{l}\text { rations equa } \\
\text { source or fin } \\
\text { gency, } 2007 \\
\text { omoform, cl }\end{array}$ & $\begin{array}{l}\text { or greater th } \\
\text { d water. } \\
\text { IBSL from } \\
\text { form, and }\end{array}$ & $\begin{array}{l}0.1 \mu \mathrm{g} / \mathrm{L} \text {. } \\
\text { ccalino and } \\
\text { romochloror }\end{array}$ & s (2007). & & & \\
\hline
\end{tabular}

\section{A Closer Look at Atrazine and its Degradates}

\section{Detections and concentrations of atrazine and atrazine} degradates are relatively similar in source and finished water. The occurrence and concentrations of degradate compounds compared to those of the parent atrazine differed slightly by degradate compound, depending on chemical properties, use, and hydrologic pathways.

The herbicide atrazine and its degradates are highlighted here because of their frequent detection nationally and locally. The percentage of detections and concentrations of atrazine and atrazine degradate compounds were relatively similar in source and finished water (fig. 2). Although concentrations of herbicide compounds generally are highest during spring applications, atrazine and two of its degradate compounds (2-hydroxyatrazine and deethylatrazine) were detected year-round, likely a result of widespread use of atrazine in agricultural and non-agricultural settings.

Summed concentrations of degradate compounds often are similar to or greater than the parent herbicide concentrations; however, for samples collected in the Elm Fork Trinity River, the summed concentrations of atrazine degradates were less than parent atrazine concentrations. Atrazine is chemically more stable, allowing it to persist longer in the hydrologic system than other herbicide compounds, which tend to break down more quickly in the soil zone (Gilliom and others, 2006).

Transformation from parent herbicide to degradate compounds usually results in conversion to less toxic compounds, but some degradates might have toxicities that are similar to, or greater than, that of the parent pesticide (Gilliom and others, 2006). Therefore, understanding the occurrence of herbicide degradate compounds such as those for atrazine is important, considering that degradate compounds are not regulated under the Safe Drinking Water Act. 


\section{Human-Health Benchmarks Used in This Study}

A screening-level assessment of the potential significance of detected compounds to human health was based on a comparison of measured concentrations to available human-health benchmarks. Specifically, concentrations of regulated compounds were compared to USEPA maximum contaminant levels, and concentrations of unregulated compounds that have USEPA-published toxicity information were compared to USGS health-based screening levels, which were developed in collaboration with USEPA, New Jersey Department of Environmental Protection, and Oregon Health \& Science University (Toccalino and others, 2007). About one-half of detected compounds do not have human-health benchmarks or adequate toxicity information for evaluating results in a human-health context. Human-health benchmarks are developed for individual compounds and not mixtures. The screening-level assessment provides an initial perspective on the potential importance of man-made organic compounds in source water; it is not a substitute for a comprehensive risk assessment, which includes many more factors, such as additional avenues of exposure.

\section{Potential Effects on Human Health}

Concentrations of all detected compounds in source and finished water generally were less than 0.1 microgram per liter and always less than human-health benchmarks, which are available for about one-half of the detected compounds.

Although the type of conventional water treatment used by this community water system (which is typical of many systems across the Nation) is not specifically designed to remove most of the organic compounds, concentrations generally were less than 0.1 microgram per liter. For perspective, reporting limits for public drinking water commonly are set through Federal regulations at 0.5 microgram per liter, and water utilities generally are not required to measure below this limit.

Concentrations of 19 compounds that were detected frequently in source or finished water, or both (table 1), were greater than 0.1 microgram per liter (table 2). In general, compounds with concentrations greater than 0.1 microgram per liter such as atrazine, two atrazine degradates, and other herbicides, reflect their relatively widespread use in the Trinity River Basin and their physical properties that allow them to persist in the environment (Gilliom and others, 2006; Zogorski and others, 2006). Concentrations did not exceed USEPA drinking-water standards (maximum contaminant level [MCL]) for regulated compounds (table 2) in any sample. Concentrations also were less than USGS health-based screening levels established for selected unregulated compounds (see inset, "Human-Health Benchmarks Used in This Study").

The USGS screening-level assessment also identified compounds at concentrations less than human-health benchmarks, but within a factor of 10 . Only six compounds were detected at concentrations within a factor of 10 of the USEPA MCL: atrazine, simazine, and total trihalomethanes (bromodichloromethane, bromoform, chloroform, and dibromochloromethane) (table 2). Although most of these compounds are regularly monitored in finished water by community water systems, those occurring in 20 percent or more of source- water samples and with concentrations within a factor of 10 of their MCL might warrant consideration in low-concentration trends monitoring to better understand their transport and fate within the watershed. Human-health benchmarks are not available for eight compounds that were detected most frequently at concentrations greater than 0.1 microgram per liter (table 2).

An important consideration in assessing potential effects on human health is the common occurrence of mixtures of organic compounds in source- and finished-water samples. For example, the median number of compounds in source-water samples at the Elm Fork Trinity River was 29. This is comparable to findings from eight additional community water systems sampled by the USGS (Kingsbury and others, 2008). The potential human-health effects of mixtures of co-occurring organic compounds are largely unknown and have not been extensively studied. The effect of one compound on another's toxicity might be additive, antagonistic, or synergistic. With a few exceptions for pesticides with common modes of action, human-health benchmarks generally are not available for specific mixtures. Continued research is needed because MCLs and other humanhealth benchmarks are based on toxicity data for individual compounds, and the effects of specific mixtures of compounds at low levels are not well understood (Gilliom and others, 2006).

\section{Elm Fork Trinity River Findings in a National Context and Possible Implications}

Overall, the compounds detected most frequently in water from the Elm Fork Trinity River (tables 1 and 2) are among those most frequently detected in ambient stream water and groundwater across the Nation (Gilliom and others, 2006; Zogorski and others, 2006). In addition, the occurrence and concentrations of compounds in source- and finished-water samples from the Elm Fork Trinity River were similar to those detected at other community water systems sampled as part of an ongoing national NAWQA investigation of rivers, many of which have upstream wastewater facilities and that drain considerable agricultural and urban land (Kingsbury and others, 2008). Findings in a national context, however, are considered preliminary because some compounds included in this study have only recently been monitored systematically in source water and finished water, including, for example, plant- or animal-derived biochemicals (such as cholesterol and 3-beta-coprostanol) and those used for personal care, such as acetyl hexamethyl tetrahydronaphthalene (AHTN) and hexahydrohexamethyl cyclopentabenzopyran (HHCB). Continued research is needed to better understand sources, transport mechanisms, trends, fate in the environment, and possible linkages of organic compounds to human health.

USGS will continue to collaborate with and complement the work of other Federal, State, and local organizations to better understand and communicate the relevance of organic compounds detected in untreated source water and treated finished water and possible implications for human health and the environment. Research is ongoing to improve our understanding of the toxicity of commonly occurring, unregulated organic compounds and mixtures of organic compounds detected in source water and finished water. Research and monitoring also are continuing to identify compounds not typically evaluated in source water, but commonly present in finished water. 


\section{Source Water-Quality Assessments by the NAWQA Program Conducted across the Nation}

Beginning in 2002, NAWQA initiated "Source Water-Quality Assessments" (SWQAs) at selected community water systems across the United States (Delzer and Hamilton, 2007). The long-term goal is to complete as many as 30 SWQAs at systems that withdraw water from streams by 2012 using standard protocols and nationally consistent methods (U.S. Geological Survey, 1997-2006).

This fact sheet highlights findings from the Trinity River study, which is one of the first nine community water systems sampled. The fact sheet serves as a companion product to a USGS Data Series and a USGS Scientific Investigations Report that present findings for the nine systems across the United States (Carter and others, 2007; Kingsbury and others, 2008). http://water.usgs.gov/nawqa/swqa

\section{References}

Carter, J.M., Delzer, G.C., Kingsbury, J.A., and Hopple, J.A., 2007, Concentration data for anthropogenic organic compounds in ground water, surface water, and finished water of selected community water systems in the United States, 2002-05: U.S. Geological Survey Data Series 268, 30 p. (http://pubs.usgs.gov/ds/2007/268)

Christman, R.F., 1980, Chemistry of the use of chlorine in water and food processing, in Jolley, R.L., Brungs, W.A., and Cumming, R.B., eds., Water chlorination, environmental impact and health effects: Ann Arbor, Mich., Ann Arbor Science Publishers, Inc., v. 3, 1,171 p.

Delzer, G.C., and Hamilton, P.A., 2007, National Water-Quality Assessment Program-Source Water-Quality Assessments: U.S. Geological Survey Fact Sheet 2007-3069, 2 p. (http://pubs.usgs.gov/ $f_{s} / 2007 / 3069$ )

Gilliom, R.J., Barbash, J.E., Crawford, C.G., Hamilton, P.A., Martin, J.D., Nakagaki, Naomi, Nowell, L.H., Scott, J.C., Stackelberg, P.E., Thelin, G.P., and Wolock, D.M., 2006, The quality of our Nation's waters-Pesticides in the Nation's streams and ground water, 1992-2001: U.S. Geological Survey Circular 1291, 172 p. (http://pubs.usgs.gov/cir/2005/1291)

Kingsbury, J.A., Delzer, G.C., and Hopple, J.A., 2008, Anthropogenic organic compounds in source water of nine community water systems that withdraw from streams, 2002-05: U.S. Geological Survey Scientific Investigations Report 2008-5208, 66 p. (http://pubs.usgs.gov/sir/2008/5208)

Krasner, S.W., Weinberg, H.S., Richardson, S.D., Pastor, S.J., Chinn, R., Sclimenti, M.J., Onstad, G.D., and Thurston, A.D., Jr., 2006, Occurrence of a new generation of disinfection byproducts: Environmental Science \& Technology, v. 40, no. 23, p. 7,175-7,185.

Land, L.F., 1991, National Water-Quality Assessment Program-The Trinity River Basin: U.S. Geological Survey Open-File Report 91-158, 2 p. (http://pubs.er.usgs.gov/usgspubs/ofr/ofr91158)

Land, L.F., and Brown, M.F., 1996, Water-quality assessment of the Trinity River Basin, Texas-Pesticides in streams draining an urban and an agricultural area, 1993-95: U.S. Geological Survey WaterResources Investigations Report 96-4114, 22 p. (http://pubs.er.usgs. gov/usgspubs/wri/wri964114)

Land, L.F., Moring, J.B., Van Metre, P.C., Reutter, D.C., Mahler, B.J., Shipp, A.A., and Ulery, R.L., 1998, Water quality in the Trinity River Basin, Texas, 1992-95: U.S. Geological Survey Circular 1171, 39 p. (http://pubs.usgs.gov/circ/circ1171/)

Magara, Y., Aizawa, T., Matumoto, N., and Souna, F., 1994, Degradation of pesticides by chlorination during water purification: Water Science and Technology, v. 30, no. 7, p. 119-128.
Rook, J.J., 1974, Formation of haloforms during chlorination of natural waters: Water Treatment and Examination, v. 23, no. 2, p. 234-243.

Toccalino, P.L., Norman, J.E., Booth, N.L., and Zogorski, J.S., 2007, Health-based screening levels-A tool for evaluating what waterquality data may mean to human health: U.S. Geological Survey, National Water-Quality Assessment Program, accessed June 5, 2008, at http://water.usgs.gov/nawqa/HBSL/.

U.S. Department of Agriculture, 2008, Agricultural Research Service (ARS), Pesticide properties database: accessed March 6, 2008, at http://www.ams.usda.gov/science/pdp/.

U.S. Environmental Protection Agency, 2007a, Setting standards for safe drinking water: U.S. Environmental Protection Agency, Office of Ground Water and Drinking Water, accessed June 1, 2007, at http://www.epa.gov/safewater/standard/setting.html

U.S. Environmental Protection Agency, 2007b, Unregulated Contaminant Monitoring Regulation (UCMR) for public water systems revisions-Final rule: Federal Register, January 4, 2007, v. 72, no. 2 , p. 367.

U.S. Environmental Protection Agency, 2007c, Unregulated Contaminant Monitoring Regulation (UCMR) for public water systems revisions-Correction: Federal Register, January 26, 2007, v. 72, no. 17 , p. 3,916 .

U.S. Geological Survey, 1997-2006, National field manual for the collection of water-quality data: U.S. Geological Survey Techniques of Water-Resources Investigations, book 9, chaps. A1-A9, available at http://water.usgs.gov/owq/FieldManual/ (chapters were originally published during 1997-99; updates and revisions are ongoing and are summarized at http://water.usgs.gov/owq/FieldManual/ mastererrata.html

Valder, J.F., Delzer, G.C., Price, C.V., and Sandstrom, M.W., 2008, Study design and percent recoveries of anthropogenic organic compounds with and without the addition of ascorbic acid to preserve water samples containing free chlorine, 2004-06: U.S. Geological Survey Open-File Report 2008-1226, 85 p. (http://pubs.usgs.gov/ of/2008/1226)

Zogorski, J.S., Carter, J.M., Ivahnenko, Tamara, Lapham, W.W., Moran, M.J., Rowe, B.L., Squillace, P.J., and Toccalino, P.L., 2006, The quality of our Nation's waters-Volatile organic compounds in the Nation's ground water and drinking-water supply wells: U.S. Geological Survey Circular 1292, 101 p. (http://pubs.usgs.gov/circ/ circ1292/)

\section{By Patricia B. Ging, Gregory C. Delzer, and Pixie A. Hamilton}

\section{USGS promotes public access to water-quality information}

This fact sheet, additional data and investigations reports, and other information are available on the World Wide Web at http://water.usgs. gov/nawqa/swqa. Included at this Web site are downloadable data on organic compound occurrence, information on sampling designs and methodology, background on data analyses, and frequently asked questions.

Any use of trade, product, or firm names is for descriptive purposes only and does not imply endorsement by the U.S. Government.

Publishing support provided by the

Lafayette Publishing Service Center
For more information, contact:

Patricia Ging, U.S. Geological Survey, (512) 927-3581, pbging@usgs.gov Bruce Moring, U.S. Geological Survey, (512) 927-3585, jbmoring@usgs.gov Greg Delzer, National Coordinator, (605) 394-3230, gcdelzer@usgs.gov 